\title{
Effect of variety and nitrogen rate on the yield performance of boro rice
}

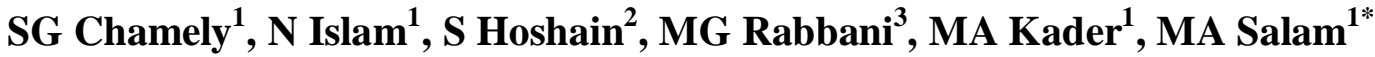

${ }^{1}$ Department of Agronomy, Bangladesh Agricultural University, Mymensingh-2202, Bangladesh; ${ }^{2}$ Department of Coastal Agriculture, Noakhali Science \& Technology University, Sonapur, Noakhali-3814, Bangladesh;

${ }^{3}$ Research Cell, Noakhali Science \& Technology University, Sonapur, Noakhali-3814, Bangladesh

\begin{abstract}
An experiment was conducted at the Agronomy Field Laboratory, Bangladesh Agricultural University, Mymensingh during the period from November 2010 to May 2011 to study the effect of variety and rate of nitrogen on the performance of Boro rice. The experiment comprised three varieties viz., BRRI dhan28 $\left(\mathrm{V}_{1}\right)$, BRRI dhan29 $\left(\mathrm{V}_{2}\right)$ and BRRI dhan45 $\left(\mathrm{V}_{3}\right)$; and five rates of nitrogen viz., control $\left(\mathrm{N}_{0}\right), 50 \mathrm{~kg}\left(\mathrm{~N}_{1}\right), 100 \mathrm{~kg}$ $\left(\mathrm{N}_{2}\right), 150 \mathrm{~kg}\left(\mathrm{~N}_{3}\right)$ and $200 \mathrm{~kg}\left(\mathrm{~N}_{4}\right) \mathrm{N} \mathrm{ha}^{-1}$. The experiment was laid out in a randomized complete block design with four replications. The growth analysis results indicate that the tallest plant $(80.88 \mathrm{~cm})$ and the highest number of total tillers hill ${ }^{-1}$ (13.80) were observed in BRRI dhan29 at 70 DATs and the highest total dry matter $\left(66.41 \mathrm{~g} \mathrm{~m}^{-2}\right)$ was observed in BRRI dhan45. The shortest plant $(78.15 \mathrm{~cm})$ and the lowest number of tillers hill ${ }^{1}$ (12.41) were recorded from BRRI dhan45 and the lowest dry matter (61.24 g) was observed in BRRI dhan29. The tallest plants $(84.01 \mathrm{~cm})$, highest number of tillers hill ${ }^{-1}(14.06)$ and the highest dry matter $\left(69.58 \mathrm{~g} \mathrm{~m}^{-2}\right)$ were obtained from $200 \mathrm{~kg} \mathrm{~N} \mathrm{ha}^{-1}$. The tallest plants $(86.48 \mathrm{~cm})$ and maximum dry matter $\left(72.30 \mathrm{~g} \mathrm{~m}^{-2}\right)$ were recorded from BRRI dhan28 with $200 \mathrm{~kg} \mathrm{~N} \mathrm{ha}^{-1}$ and BRRI dhan45 with $200 \mathrm{~kg} \mathrm{~N} \mathrm{ha}^{-1}$, respectively. The highest number of tillers hill ${ }^{-1}$ (15.14) was obtained from BRRI dhan29 with $50 \mathrm{~kg} \mathrm{~N} \mathrm{ha}^{-1}$. The harvest data reveal that variety had significant effect on total tillers hill ${ }^{-1}$, effective tillers hill ${ }^{-1}$, non-effective tillers hill ${ }^{-1}$, panicle length, grain yield, straw yield and harvest index. The highest grain yield (4.84 $\mathrm{t} \mathrm{ha}^{-1}$ ) was recorded from BRRI dhan29. The results of the experiment also indicate that total tillers hill ${ }^{-1}$, effective tillers hill ${ }^{-1}$, grains panicle ${ }^{-1}$, sterile spikelets panicle ${ }^{-1}$, grain yield, straw yield and harvest index were significantly affected by levels of nitrogen, while plant height, panicle length, 1000-grain weight were not significantly affected by levels of nitrogen. The highest grain yield (5.58 $\mathrm{t} \mathrm{ha}^{-1}$ ) was obtained from $200 \mathrm{~kg} \mathrm{~N} \mathrm{ha}^{-1}$. Interaction effect of variety $\times 200 \mathrm{~kg} \mathrm{~N} \mathrm{ha}^{-1}$ produced the highest grain yield $\left(5.82 \mathrm{t} \mathrm{ha}^{-1}\right)$. From the results of the study it may be concluded that BRRI dhan29 rice may be cultivated with $200 \mathrm{~kg} \mathrm{~N} \mathrm{ha}^{-1}$ for obtaining higher yield in AEZ 9 of Bangladesh.
\end{abstract}

Key words: Boro rice, $\mathrm{N}$ level, variety, yield

Progressive Agriculturists. All rights reserved.

*Corresponding Author: salamma71@yahoo.com

\section{Introduction}

The population of our country is increasing but the cultivable land is decreasing due to urbanization and industrialization resulting in more shortage of food. Thus, Bangladesh will require about 27.26 million tons of rice for the year 2020. Since it is not possible to have horizontal expansion of rice area, rice yield should be increased to meet this ever increasing demand of food. The rainfed Aus, the rainfed Aman and irrigated Boro rice are cultivated in 10\%, 51\% and $39 \%$ in the total cropped area in Bangladesh, respectively (BADC, 2008). But according to BBS Report 2008 Aus, Aman and Boro produced 1.51, 9.66 and 17.76 million metric tons of rice. Therefore, Boro rice is one of the most important rice crops for Bangladesh with respect to its high yield and contribution to rice production.

Variety plays an important role in augmenting yield of rice. Use of HYV has been increased remarkably 
in recent years and the country has almost reached a level of self sufficiency in food. National Commission of Agriculture projected that to remain self-sufficient Bangladesh will need to produce 47 million MT of paddy (31.6 million MT of rice) by the year 2020, implying a required rate of growth of production at $1.7 \%$ per year. An earlier Agricultural Research Strategy document prepared by the Bangladesh Agricultural Research Council projected the required paddy production by 2020 of 52 million MT (34.7 million MT of rice), which would require a production growth of $2.2 \%$ per year. The adoption of HYV rice technology, which enabled Bangladesh to double the yield rate during 1969-70 to 1998-99, was not however an unmixed blessing (GOB, 1998). The lion share of self sufficiency is obtained through the expansion of HYV rice cultivation in the Boro season. However, many of them are not known to have been studied to their yield and yield contributing characters. Bangladesh Rice Research Institute (BRRI) released a number of cultivars to cultivate in Boro season with detailed study for their different agronomic traits to furnish worth information regarding yield and possibilities for varietal improvement. Among the Boro rice varieties, BRRI dhan28, BRRI dhan 29 and BRRI dhan 45 are most popular varieties and produced higher yield than other Boro rice varieties.

Nitrogen is a major essential plant nutrient and a key input for increasing crop yield. Rice plants require a large amount of nitrogen at the early and midtillering stage to maximize the number of panicles. In order to exploit the full yield potential of modern rice cultivars, $\mathrm{N}$-fertilizer application is necessary in most soils. Nitrogen is the most deficient nutrient element in Bangladesh soils and almost every farmer has to apply the costly N-fertilizer to get a desirable yield of rice. Optimum dose of nitrogen fertilization plays a vital role in growth and development of rice plant. Rice growth is seriously hampered when lower dose of nitrogen is applied which drastically reduces yield. Nitrogen has a positive influence on the production of effective tillers per plant, yield and yield attributes. On the other hand, excessive nitrogen fertilization encourages excessive vegetative growth which makes the plant susceptible to insects, pests and diseases and ultimately reduces yield. Rice grain yield was recorded significantly highest between ranges of 90-250 kg ha ${ }^{-1}$ nitrogen application (Marazi et al., 1993; Daniel and Wahab, 1994; Bali et al., 1995; Meena et al., 2003). A significant increase in tillering (Hussain et al., 1989; Meena et al., 2003) with increase in nitrogen supply was observed. By applying proper dose we can save money and can also keep our environment sound. A suitable combination of variety and rate of nitrogen is necessary for better yield.

Keeping above facts in mind the present study was, therefore, undertaken to observe the varietal performance of Boro rice, to evaluate the effect of rate of nitrogen on the yield of Boro rice and to find out the interaction effect of variety and nitrogen rate, if any, on the yield of Boro rice.

\section{Materials and Methods}

\section{Location}

The experiment was carried out at the Agronomy Field Laboratory, Bangladesh Agricultural University (BAU), Mymensingh during the period from November 2010 to May 2011 to study the effect of variety and nitrogen rate on the growth and yield performance of Boro rice.

\section{Soil}

The experimental site belongs to the Sonatola soil series under the Old Brahmaputra Floodplain Agroecological zone (AEZ-9) having non-calcareous dark grey floodplain soil (UNDP and FAO, 1988). Soil of the experimental site was more or less neutral in reaction, low in organic matter content and its general fertility level was also low.

\section{Experimental treatment and design}

The study consisted of two factor A: Variety- threei) BRRI dhan28 $\left(\mathrm{V}_{1}\right)$, (ii) BRRI dhan29 $\left(\mathrm{V}_{2}\right)$, and ( iii) BRRI dhan45 $\left(\mathrm{V}_{3}\right)$; and factor $\mathrm{B}$ : Level of nitrogen- (i) 0 or control treatment $\left(\mathrm{N}_{0}\right)$, (ii) 50 $\left(\mathrm{N}_{1}\right)$, (iii) $100\left(\mathrm{~N}_{2}\right), 150\left(\mathrm{~N}_{3}\right)$ and $200\left(\mathrm{~N}_{4}\right) \mathrm{kg}$ nitrogen $\mathrm{ha}^{-1}$. The experiment was laid out in a randomized complete block design with four replications. Each of the replication represented a block in the experiment. Each block was divided into 15 unit plots where 15 treatment combinations were 
allocated at random. There were 60 plots in the experiment. The size of unit plot was $4.0 \mathrm{~m} \times 2.5 \mathrm{~m}$. The distance maintained between two unit plots was $0.50 \mathrm{~m}$ and between blocks was $1 \mathrm{~m}$. Treatments were randomly allocated in the experiment.

\section{Seedling emergence}

Seeds were immersed in water in bucket for 24 hours. Then seeds were taken out of water and kept thickly in gunny bags. The seeds started sprouting after 48 hours and were sown after 72 hours. Then the sprouted seeds were sown in the nursery bed on 30 November 2010.

\section{Field preparation and fertilization}

The land was puddled thoroughly by repeated ploughing and cross ploughing with a country plough and subsequently leveled by laddering. The field layout was made on 5 January 2011. In the experiment, full doses of fertilizers viz., triple super phosphate $\left(120 \mathrm{~kg} \mathrm{ha}^{-1}\right)$, muriate of potash $(70 \mathrm{~kg} \mathrm{ha}$ $\left.{ }^{1}\right)$, gypsum (60 kg ha-1 $)$ and zinc sulphate $\left(10 \mathrm{~kg} \mathrm{ha}^{-1}\right)$ were applied at the time of final land preparation. Urea $\left(0,50,100,150\right.$ and $\left.200 \mathrm{~kg} \mathrm{ha}^{-1}\right)$ was top dressed in equal installments at 15, 30 and 45 DAT.

\section{Rice transplanting}

Thirty five-day-old seedlings were uprooted carefully from the nursery bed and transplanted on 5 January 2011 at the rate of three seedlings hill ${ }^{-1}$ maintaining a spacing of $25 \mathrm{~cm} \times 15 \mathrm{~cm}$. Three weedings were done in order to keep the crop weed free at 15, 30 and 45 DAT.

\section{Data collection}

Three hills (excluding border hill) were selected at random from each plot and tagged for measuring plant height and counting the number of tillers at 25, 40, 55 and 70 DAT. Maturity of the crop was determined when $90 \%$ of the seeds become golden yellow in color. The crops were harvested at full maturity on 17 April 2011 (BRRI dhan28), 28 April 2011 (BRRI dhan45) and 8 May 2011 (BRRI dhan29). In each plot central $1 \mathrm{~m} \times 1 \mathrm{~m}$ area was harvested to record the yields of grain and straw. Three hills that are randomly selected for measuring growth parameters were used to record the data on yield contributing characters. The harvested crop of each plot was separately bundled, properly tagged and then brought to the threshing floor. The harvested crops were threshed by pedal thresher and the fresh weight of grain and straw was recorded plot-wise. Grains were cleaned and dried to a moisture content of $14 \%$. Straws were sun dried properly. Final grain and straw yields plot ${ }^{-1}$ were recorded and converted to $t \mathrm{ha}^{-1}$. At vegetative stage data were collected on plant height, total tillers hill $^{-1}$ and total dry matter $\left(\mathrm{g} \mathrm{m}^{-2}\right)$. To determine dry matter the sample plants were first air dried for 6-8 hours. Then the samples were packed in labeled brown paper bag and dried in the oven at $85 \pm 5^{\circ} \mathrm{C}$ for 24 hours until constant weight was reached. After oven drying, the samples were weighed by using electric balance.

\section{Statistical analysis}

Collected data were compiled and tabulated in proper form for statistical analysis. The recorded data in variation plant characters were statistically analyzed to find out the significance of variation resulting from the experimental treatments. At harvest, data were collected on plant height, total tillers hill ${ }^{-1}$, effective tillers hill ${ }^{-1}$, non effective tillers hill ${ }^{-1}$, length of panicle, grains panicle ${ }^{-1}$, sterile spikelets panicle $^{-1}$, 1000-grain weight, grain yield, straw yield and harvest index. Collected data were analyzed using "Analysis of Variance Technique" with the help of a computer package programmes MSTAT and the mean differences were adjudged by Duncan's Multiple Range Test (Gomez and Gomez, 1984).

\section{Results and Discussion}

\section{Effect of variety on growth parameters}

Variety exerted significant influence on plant height at 25 and $70 \mathrm{D}$ ATs, number of total tillers hill ${ }^{-1}$ at 40 and 55 DATs and dry matter production at all sampling dates (Fig.1, 3 and 5). At 25 and 70 DATs, the tallest plant $(33.40 \mathrm{~cm}$ and $80.88 \mathrm{~cm})$ was found in the variety BRRI dhan29 (Fig. 1). Plant height is a varietal character and it is the genetic constituent of the cultivar, therefore, plant height was different among the cultivars. At all sampling dates except 25 DAT, variety BRRI dhan29 produced the highest number of total tillers hil ${ }^{1-1}$ (Fig. 3). The results indicate that tillering pattern of different varieties differed due to genetic potentiality of the varieties. 
BRRI (1985) and Babiker (1986) also found varietal differences of tillering in the medium and traditional varieties. The increasing pattern of dry matter (DM) production was not similar among the varieties. Variety BRRI dna28 produced the highest DM at different DATs (Fig. 5). The significant variation in DM production among the varieties was also reported by Shamsuddin et al. (1988).

\section{Effect of level of nitrogen on growth parameters}

Plant height, total tillers hill ${ }^{-1}$, leaf area and total DM production was significantly affected by different nitrogen levels at all sampling dates (Fig. 2, 4 and 6). The tallest plant was recorded at $200 \mathrm{~kg} \mathrm{~N} \mathrm{ha}^{-1}$ at all sampling dates and the lowest one was recorded in control $\left(0 \mathrm{~kg} \mathrm{~N} \mathrm{ha}^{-1}\right)$ treatment at all sampling dates (Fig. 2). The highest number of total tillers hill ${ }^{-1}$ was obtained from $200 \mathrm{~kg} \mathrm{ha}^{-1}$ at all sampling dates but at 55 and 70 DATs, it was statistically identical with $100 \mathrm{~kg} \mathrm{~N} \mathrm{ha}^{-1}$ (Fig. 4). At all sampling dates, the highest dry matter (13.49, 23.47, 53.89 and $69.58 \mathrm{~g}$ $\mathrm{m}^{-2}$ ) was produced from $200 \mathrm{~kg} \mathrm{~N}^{-1}$ (Fig. 6). Similar research finding was also reported by Kumar et al. (1996).

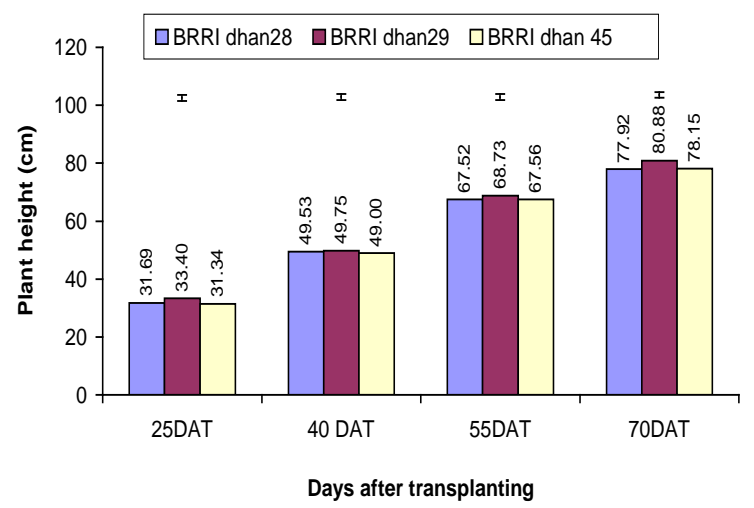

Fig. 1 Effect of variety on the plant height of Boro rice

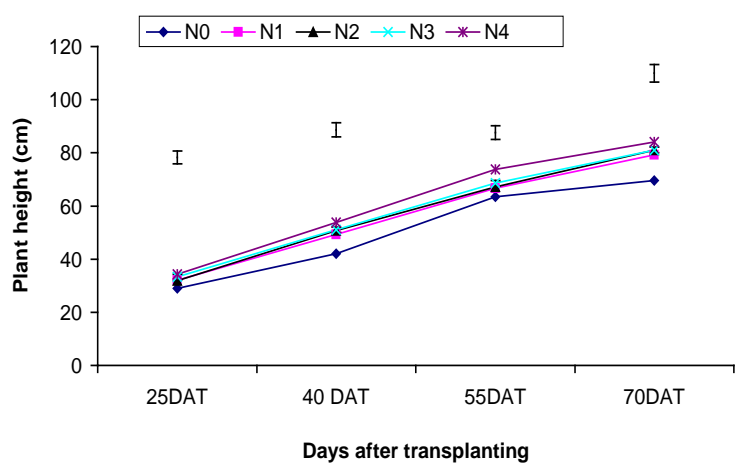

Fig. 2 Effect of levels of nitrogen on the plant height of Boro rice

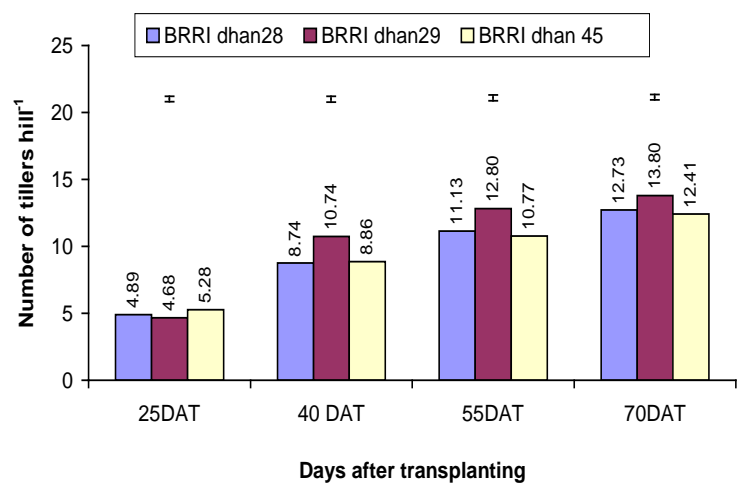

Fig. 3 Effect of variety on the number of tillers hill ${ }^{-1}$ of Boro rice

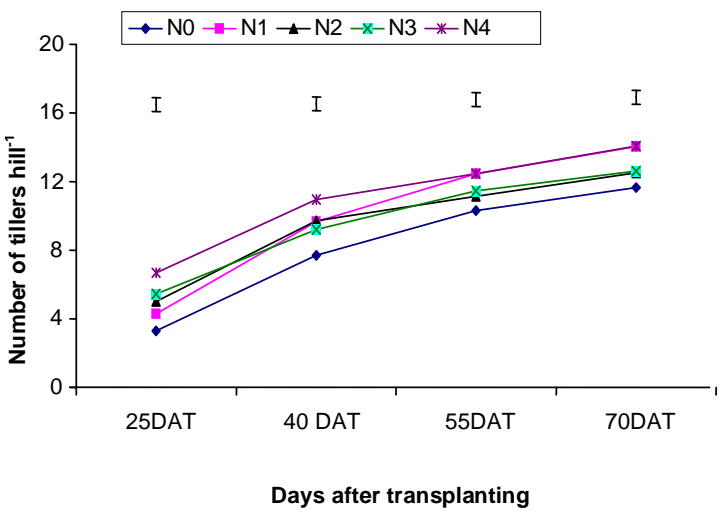

Fig. 4 Effect of levels of nitrogen on the tillers hill ${ }^{-1}$ of boro rice

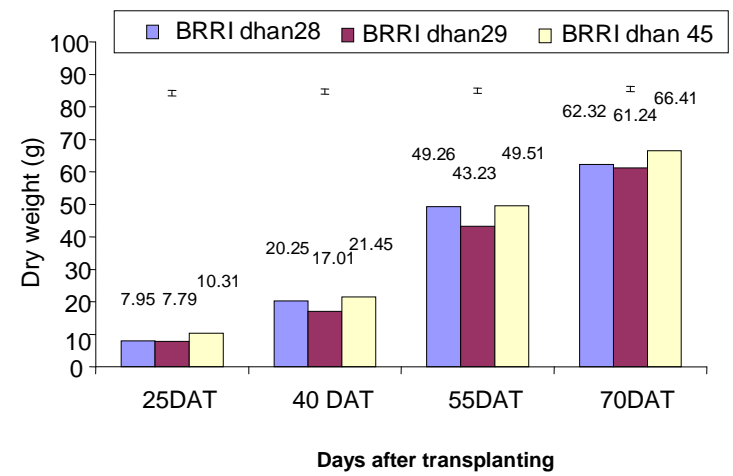

Fig. 5 Effect of variety on dry weight $(g)$ of Boro rice

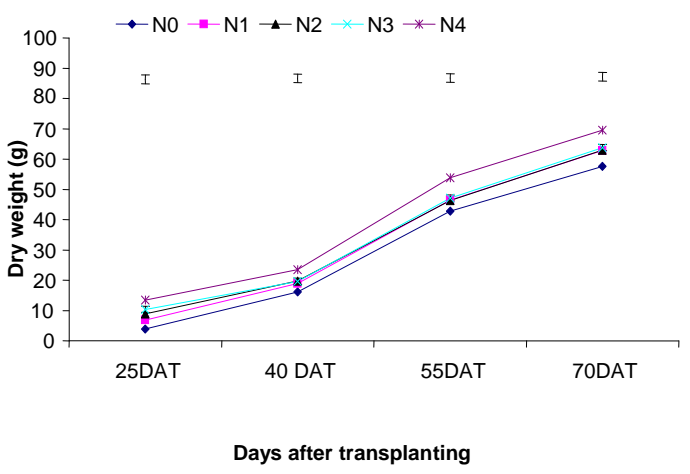

Fig. 6 Effect of levels of nitrogen on dry weight (g) of Boro rice 


\section{Effect of interaction of variety and level of nitrogen on growth parameters}

The interaction between variety and level of nitrogen was significant on plant height at 55 and 70 DAT, was not significant on number of total tillers hill ${ }^{-1}$ and significant on dry matter production at 50 and 70 DAT (Table 1). The tallest plant $(86.48 \mathrm{~cm})$, was recorded from BRRI dhan 28 with $200 \mathrm{~kg} \mathrm{~N} \mathrm{ha}^{-1}$, the highest number of tillers hill ${ }^{-1}$ (15.14) and the highest dry matter $\left(72.30 \mathrm{~g} \mathrm{~m}^{-2}\right)$ was produced by BRRI dhan 45 with $200 \mathrm{~kg} \mathrm{~N} \mathrm{ha}^{-1}$.

Yield and yield contributing characters of boro rice as influenced by variety and level of nitrogen

\section{Effect of variety}

Variety exerted significant effect on all the yield and yield contributing characters of boro rice except plant height (Table 2). The highest number of total tillers hill $^{-1}$ (12.71) was recorded in the variety BRRI dhan29 which was statistically similar with the variety BRRI dhan 28 and the lowest number of total tillers hill ${ }^{-1}$ was observed in BRRI dhan45. The highest number of effective tillers hill ${ }^{-1}$ (11.07) was recorded in the variety BRRI dhan29 and the lowest one was observed in BRRI dhan45. The reasons for differences in producing bearing tillers hill ${ }^{-1}$ might be due to the variation in genetic make-up of the variety that might be influenced by heredity. This was consistent with Chowdhury et al. (1993). The longest panicle $(23.19 \mathrm{~cm})$ was found in the variety BRRI dhan29 and the smallest one was observed in BRRI dhan45. The variation as assessed might be due to genetic characters of the varieties primarily influenced by the heredity. Diaz et al. (2000) also reported that panicle length varied among varieties. The highest number of grains panicle ${ }^{-1}$ (159.55) was recorded in the variety BRRI dhan29 which was about double compare to the variety BBRI dhan 45 and about 1.5 fold more than the variety BRRI dhan28. Differences in number of grains panicle ${ }^{-1}$, due to varieties were reported by BRRI (1994). Varietal differences regarding the number of grains panicle $^{-1}$ was probably due to their genetic makeup and also due to the variation in photosynthetic assimilate accumulation especially after heading. The highest grain yield was recorded from the variety BRRI dhan29 which might be due to the highest number of total tillers hill ${ }^{-1}$, highest number of effective tillers hill ${ }^{-1}$ and highest number of grains panicle $^{-1}$ in the cultivar BRRI dhan29. The highest straw yield was observed in the variety BRRI dhan28. This was due to the higher total DM production in the cultivar BRRI dhan28. The highest harvest index was found in the variety BRRI dhan 29 (Table 2).

\section{Effect of level of nitrogen}

The result of the study reveals that number of total tillers hill ${ }^{-1}$, effective tillers hill ${ }^{-1}$, number of grains panicle $^{-1}$, grain yield, straw yield and harvest index varied significantly due to different levels of nitrogen (Table 3). The highest number of total tillers hill ${ }^{-1}$ (14.05) was found with the application of $200 \mathrm{~kg} \mathrm{~N}$ $\mathrm{ha}^{-1}$ and the lowest number of total tillers hill ${ }^{-1}$ was found in control treatment. Nitrogen is an element which enhances vegetative growth of plants. Therefore, with the positive physiological effects the number of tillers hill ${ }^{-1}$ increased with the increase in nitrogen dose. The highest number of effective tillers hill $^{-1}$ (12.57) was observed when $\mathrm{N}$ was used at the rate of $200 \mathrm{~kg} \mathrm{ha}^{-1}$ and the lowest one was observed in control $\left(0 \mathrm{~kg} \mathrm{~N} \mathrm{ha}{ }^{-1}\right)$ treatment (Table 4). Adequacy of $\mathrm{N}$ probably favored the cellular activity during panicle initiation and development that led to increase the number tillers hill ${ }^{-1}$. The results agreed with those of Balasubramaniyan (1984), Gosh et al. (1991), Pandey et al. (1991) and Thakur (1993). Panicle length was not significantly influenced by different levels of nitrogen. The highest number of grains panicle $^{-1}$ (125.90) was recorded with the application of $200 \mathrm{~kg} \mathrm{~N} \mathrm{ha}^{-1}$ and the lowest one was found from control $\left(0 \mathrm{~kg} \mathrm{~N} \mathrm{ha}^{-1}\right)$ treatment which is the indication of grains panicle ${ }^{-1}$ increased with the increased use of $\mathrm{N}$ level. The highest number of sterile spikelets panicle ${ }^{-1}$ was observed in control $(0$ $\mathrm{kg} \mathrm{N} \mathrm{ha}{ }^{-1}$ ) and the lowest number of grains panicle ${ }^{-1}$ was recorded with the application of $200 \mathrm{~kg} \mathrm{~N} \mathrm{ha}^{-1}$. This result indicates that increasing $\mathrm{N}$ level decreased the sterile spikelets panicle ${ }^{-1}$. The highest grain yield (5.58 $\mathrm{t} \mathrm{ha}{ }^{-1}$ ) was found with the application of $200 \mathrm{~kg} \mathrm{~N} \mathrm{ha}^{-1}$ and the lowest grain yield was obtained from control $\left(0 \mathrm{~kg} \mathrm{~N} \mathrm{ha}^{-1}\right)$. Increase in grain yield due to increased level of nitrogen was mainly due to the improvement of 


\section{Variety and nitrogen on yield of boro rice}

growth parameters like number of total tillers hill ${ }^{-1}$ and DM production at different DATs, and improvement of yield and yield contributing characters like number of effective tillers hill ${ }^{-1}$ and number of grains panicle ${ }^{-1}$. The highest straw yield (6.12 $\mathrm{t} \mathrm{ha}^{-1}$ ) and harvest index (47.66\%) were obtained from $200 \mathrm{~kg} \mathrm{~N} \mathrm{ha}^{-1}$ (Table 3).

Table 1. Interaction effect of variety and level of nitrogen on plant height, tillers hill ${ }^{-1}$ and crop dry weight at different DATs

\begin{tabular}{|c|c|c|c|c|c|c|c|c|c|c|c|c|}
\hline \multirow[t]{2}{*}{ Variety $\times \mathrm{N}$ level } & \multicolumn{4}{|c|}{ Plant height (cm) } & \multicolumn{4}{|c|}{ Tillers hill-1 (no.) } & \multicolumn{4}{|c|}{ Crop dry weight $\left(\mathrm{g} \mathrm{m}^{-2}\right.$.) } \\
\hline & 25 DAT & 40 DAT & 55 DAT & 70 DAT & 25 DAT & 40 DAT & 55 DAT & 70 DAT & 25 DAT & 40 DAT & 55 DAT & 70 DAT \\
\hline $\mathrm{V}_{1} \mathrm{~N}_{0}$ & 28.70 & 40.80 & $61.83 f$ & $64.31 \mathrm{e}$ & 2.66 & 7.70 & 9.02 & 9.41 & 3.06 & 16.90 & 46.15de & $60.45 \mathrm{e}$ \\
\hline $\mathrm{V}_{1} \mathrm{~N}_{1}$ & 29.00 & 47.00 & 64.50 ef & $76.06 \mathrm{bcd}$ & 3.40 & 8.36 & 12.30 & 13.92 & 6.18 & 19.68 & 47.94cd & $59.42 \mathrm{e}$ \\
\hline $\mathrm{V}_{1} \mathrm{~N}_{2}$ & 30.65 & 50.10 & $70.35 a-d$ & $79.85 a b c$ & 5.27 & 9.08 & 10.56 & 12.70 & 8.04 & 19.91 & $47.28 \mathrm{cde}$ & $60.56 \mathrm{e}$ \\
\hline $\mathrm{V}_{1} \mathrm{~N}_{3}$ & 35.62 & 54.11 & 73.60ab & $82.90 \mathrm{ab}$ & 6.18 & 8.55 & 10.96 & 13.13 & 9.93 & 21.02 & $50.15 b c$ & $63.44 \mathrm{cde}$ \\
\hline $\mathrm{V}_{1} \mathrm{~N}_{4}$ & 34.50 & 55.65 & $63.38 f$ & $86.48 a$ & 6.96 & 10.03 & 12.81 & 14.47 & 12.55 & 23.74 & $54.80 \mathrm{a}$ & 67.76abc \\
\hline $\mathrm{V}_{2} \mathrm{~N}_{0}$ & 30.62 & 42.11 & 65.65def & $73.65 \mathrm{~cd}$ & 3.11 & 8.02 & 11.51 & 12.81 & 3.97 & 13.01 & $38.35 \mathrm{~g}$ & $53.71 f$ \\
\hline $\mathrm{V}_{2} \mathrm{~N}_{1}$ & 33.90 & 50.40 & $65.45 c-f$ & $82.15 a b$ & 4.14 & 11.37 & 13.90 & 15.14 & 6.26 & 15.89 & $41.31 \mathrm{fg}$ & 61.86de \\
\hline $\mathrm{V}_{2} \mathrm{~N}_{2}$ & 34.75 & 53.55 & $67.45 c-f$ & 82.70ab & 4.05 & 10.94 & 12.07 & 12.75 & 7.63 & 18.17 & $41.48 \mathrm{fg}$ & $60.28 \mathrm{e}$ \\
\hline $\mathrm{V}_{2} \mathrm{~N}_{3}$ & 32.35 & 49.60 & 71.50abc & 82.85ab & 5.37 & 11.01 & 13.01 & 13.86 & 9.43 & 16.56 & $41.83 f g$ & $61.70 \mathrm{de}$ \\
\hline $\mathrm{V}_{2} \mathrm{~N}_{4}$ & 35.40 & 53.10 & $75.68 a$ & $83.05 a b$ & 6.73 & 12.36 & 13.52 & 14.44 & 11.65 & 21.40 & 53.20ab & 68.67ab \\
\hline $\mathrm{V}_{3} \mathrm{~N}_{0}$ & 27.80 & 43.28 & 65.18def & $70.89 d$ & 4.13 & 7.44 & 10.38 & 12.72 & 4.55 & 18.50 & 44.13ef & $58.40 \mathrm{e}$ \\
\hline $\mathrm{V}_{3} \mathrm{~N}_{1}$ & 33.45 & 50.66 & 70.05b-e & 79.48abc & 5.35 & 9.22 & 11.19 & 13.08 & 8.22 & 21.01 & $50.11 b c$ & $67.07 \mathrm{bc}$ \\
\hline $\mathrm{V}_{3} \mathrm{~N}_{2}$ & 30.30 & 48.75 & $66.55 c-f$ & $80.35 a b c$ & 5.71 & 9.12 & 10.81 & 12.07 & 10.78 & 21.04 & $50.13 b c$ & $67.93 a b c$ \\
\hline $\mathrm{V}_{3} \mathrm{~N}_{3}$ & 31.90 & 49.45 & $63.85 f$ & $77.55 \mathrm{bcd}$ & 4.83 & 8.05 & 10.44 & 10.88 & 11.72 & 21.41 & $49.50 \mathrm{~cd}$ & $66.34 \mathrm{bcd}$ \\
\hline $\mathrm{V}_{3} \mathrm{~N}_{4}$ & 33.23 & 52.88 & 72.15abc & 82.49ab & 6.37 & 10.48 & 11.03 & 13.28 & 16.27 & 25.28 & $53.68 a$ & $72.30 \mathrm{a}$ \\
\hline CV(\%) & 9.54 & 7.03 & 5.05 & 5.45 & 5.27 & 6.22 & 11.00 & 25.13 & 3.56 & 4.36 & 3.02 & 2.96 \\
\hline $\begin{array}{c}\text { Level of } \\
\text { significance }\end{array}$ & NS & NS & 0.01 & 0.05 & NS & NS & NS & NS & NS & NS & 0.01 & 0.01 \\
\hline
\end{tabular}

In a column, figures with same letter or without letter do not differ significantly whereas figures with dissimilar letters differ significantly (as per DMRT), NS = Not significant, $\mathrm{V}_{1}=\mathrm{BRRI}$ dhan28, $\mathrm{V}_{2}=\mathrm{BRRI}$ dhan29, $\mathrm{V}_{3}=\mathrm{BRRI}$ dhan45

$\mathrm{N}_{0}=0$ (Control), $\mathrm{N}_{1}=50 \mathrm{~kg} \mathrm{~N} \mathrm{ha}^{-1}, \mathrm{~N}_{2}=100 \mathrm{~kg} \mathrm{~N} \mathrm{ha}^{-1}, \mathrm{~N}_{3}=150 \mathrm{~kg} \mathrm{~N}$ ha-1 $^{-1}$ and $\mathrm{N}_{4}=200 \mathrm{~kg} \mathrm{~N}^{-1}$

Table 2. Effect of variety on yield and yield contributing characters of Boro rice

\begin{tabular}{|c|c|c|c|c|c|c|c|c|c|c|}
\hline Variety & \begin{tabular}{|c|} 
Plant height \\
$(\mathrm{cm})$
\end{tabular} & $\begin{array}{c}\text { Total } \\
\text { tillers hill-1 } \\
\text { (no.) }\end{array}$ & $\begin{array}{l}\text { Effective } \\
\text { tillers hill-1 } \\
\text { (no.) }\end{array}$ & $\begin{array}{c}\text { Panicle } \\
\text { length }(\mathrm{cm})\end{array}$ & $\begin{array}{c}\text { Grains } \\
\text { panicle-1(no.) }\end{array}$ & $\begin{array}{c}\text { Sterile } \\
\text { spikelets } \\
\text { panicle-1 (no.) }\end{array}$ & $\begin{array}{l}1000 \text { - grain } \\
\text { weight }(\mathrm{g})\end{array}$ & $\begin{array}{c}\text { Grain yield } \\
\left(\mathrm{t} \mathrm{ha}^{-1}\right)\end{array}$ & $\begin{array}{c}\text { Straw yield } \\
\left(\mathrm{t} \mathrm{ha} \mathrm{a}^{-1}\right)\end{array}$ & $\begin{array}{l}\text { Harvest } \\
\text { index (\%) }\end{array}$ \\
\hline BRRI dhan28 & 73.44 & $12.11 \mathrm{a}$ & $9.55 b$ & 21.30b & $97.12 b$ & $14.76 b$ & $22.67 b$ & $4.73 b$ & $5.83 a$ & $44.63 b$ \\
\hline BRRI dhan29 & 74.93 & $12.71 \mathrm{a}$ & $11.07 a$ & $23.19 a$ & $159.55 a$ & 17.81ab & $22.53 b$ & $4.84 a$ & $5.51 a b$ & $46.51 a$ \\
\hline BRRI dhan45 & 74.16 & $9.29 b$ & $7.52 \mathrm{C}$ & $19.21 \mathrm{c}$ & $65.57 c$ & $18.57 \mathrm{a}$ & $27.75 a$ & $4.39 c$ & $5.32 b$ & $45.15 a b$ \\
\hline CV (\%) & 19.34 & 10.94 & 13.04 & 15.89 & 7.48 & 10.58 & 9.31 & 14.82 & 10.14 & 4.97 \\
\hline Level of & NS & 0.01 & 0.01 & 0.01 & 0.01 & 0.01 & 0.01 & 0.01 & 0.01 & 0.01 \\
\hline
\end{tabular}

In a column, figures with same letters or without letter do not differ significantly whereas figures with dissimilar letter differ significantly (as per DMRT), NS = Not significant. 
Table 3. Effect of levels of nitrogen on yield and yield contributing characters of three varieties of Boro rice

\begin{tabular}{|c|c|c|c|c|c|c|c|c|c|c|}
\hline $\begin{array}{l}\text { Levels } \\
\text { of nitrogen } \\
\left(\mathrm{kg} \mathrm{ha}^{-1}\right)\end{array}$ & \begin{tabular}{|c|} 
Plant height \\
$(\mathrm{cm})$
\end{tabular} & $\begin{array}{c}\text { Total } \\
\text { tillers } \\
\text { hill-1(no.) } \\
\end{array}$ & $\begin{array}{c}\text { Effective } \\
\text { tillers } \\
\text { hill-1 (no.) }\end{array}$ & $\begin{array}{c}\text { Panicle } \\
\text { length }(\mathrm{cm})\end{array}$ & $\begin{array}{c}\text { Grains } \\
\text { panicle-1 } \\
\text { (no.) } \\
\end{array}$ & $\begin{array}{c}\text { Sterile spikelets } \\
\text { panicle-1 } \\
\text { (no.) }\end{array}$ & $\begin{array}{l}\text { 1000- grain } \\
\text { weight }(\mathrm{g})\end{array}$ & $\begin{array}{c}\text { Grain yield } \\
\left(\mathrm{t} \mathrm{ha}^{-1}\right)\end{array}$ & $\begin{array}{c}\text { Straw yield } \\
\left(\mathrm{t} \mathrm{ha}^{-1}\right)\end{array}$ & $\begin{array}{l}\text { Harvest } \\
\text { index (\%) }\end{array}$ \\
\hline 0 & 73.77 & $7.46 \mathrm{e}$ & $5.43 e$ & 21.47 & $79.96 \mathrm{e}$ & $24.85 a$ & 24.53 & $3.54 \mathrm{e}$ & $4.93 e$ & $41.82 \mathrm{C}$ \\
\hline 50 & 74.24 & $9.95 d$ & $7.76 \mathrm{~d}$ & 21.43 & $100.42 d$ & $18.21 \mathrm{~b}$ & 24.38 & $4.43 d$ & $5.33 d$ & $45.37 \mathrm{~b}$ \\
\hline 100 & 73.10 & $12.32 \mathrm{C}$ & $9.89 \mathrm{c}$ & 21.02 & $108.27 \mathrm{c}$ & $16.52 b$ & 24.06 & $4.73 \mathrm{c}$ & $5.55 \mathrm{c}$ & $46.05 b$ \\
\hline 150 & 73.05 & $13.06 \mathrm{~b}$ & $11.24 b$ & 21.08 & $122.51 \mathrm{~b}$ & $13.04 \mathrm{c}$ & 24.29 & $5.00 \mathrm{~b}$ & $5.83 b$ & $46.23 b$ \\
\hline 200 & 76.72 & $14.05 a$ & $12.57 a$ & 21.16 & $125.90 \mathrm{a}$ & $12.62 \mathrm{c}$ & 24.33 & $5.58 a$ & $6.12 a$ & $47.66 \mathrm{a}$ \\
\hline CV (\%) & 19.34 & 10.94 & 13.04 & 15.89 & 7.48 & 10.58 & 9.31 & 14.82 & 10.14 & 4.97 \\
\hline $\begin{array}{c}\text { Level of } \\
\text { significance }\end{array}$ & NS & 0.01 & .01 & NS & 0.01 & 0.01 & 0.01 & 0.01 & 0.01 & 0.01 \\
\hline
\end{tabular}

In a column, figures with same letters or without letter do not differ significantly whereas figures with dissimilar letter differ significantly (as per DMRT), NS = Not significant.

Table 4. Interaction effect of variety and level of nitrogen on the yield and yield contributing characters of Boro rice

\begin{tabular}{|c|c|c|c|c|c|c|c|c|c|c|}
\hline $\begin{array}{l}\text { Interaction } \\
\text { (Varietyx } \\
\text { Nitrogen) }\end{array}$ & $\begin{array}{l}\text { Plant } \\
\text { height } \\
(\mathrm{cm})\end{array}$ & $\begin{array}{l}\text { Total } \\
\text { tillers hill-1 } \\
\text { (no.) }\end{array}$ & $\begin{array}{l}\text { Effective } \\
\text { tillers hill-1 } \\
\text { (no.) }\end{array}$ & $\begin{array}{l}\text { Panicle } \\
\text { length } \\
\text { (cm) }\end{array}$ & $\begin{array}{l}\text { Grains } \\
\text { panicle-1 } \\
\text { (no.) }\end{array}$ & $\begin{array}{c}\text { Sterile } \\
\text { spikelets } \\
\text { panicle-1 } \\
\text { (no.) }\end{array}$ & $\begin{array}{c}1000- \\
\text { grain } \\
\text { weight } \\
(\mathrm{g})\end{array}$ & $\begin{array}{l}\text { Grain } \\
\text { yield } \\
\left(\mathrm{t} \mathrm{ha}^{-1}\right)\end{array}$ & $\begin{array}{l}\text { Straw } \\
\text { yield } \\
\left(\mathrm{t} \mathrm{ha}^{-1}\right)\end{array}$ & $\begin{array}{c}\text { Harvest } \\
\text { index (\%) }\end{array}$ \\
\hline $\mathrm{V}_{1} \times \mathrm{N}_{0}$ & 72.71 & $7.99 f$ & 5.45 & 21.67 & $61.27 \mathrm{jk}$ & $23.68 b$ & 22.83 & $3.49 f$ & $5.04 d$ & $40.97 d$ \\
\hline $\mathrm{V}_{1} \times \mathrm{N}_{1}$ & 73.80 & $10.36 \mathrm{e}$ & 7.73 & 21.72 & $93.60 \mathrm{~h}$ & 13.99fgh & 22.45 & $4.54 \mathrm{~cd}$ & $5.43 \mathrm{bcd}$ & $45.63 b c$ \\
\hline $\mathrm{V}_{1} \times \mathrm{N}_{2}$ & 72.66 & $13.11 \mathrm{C}$ & 9.55 & 21.36 & $100.67 \mathrm{~g}$ & 13.95fgh & 22.54 & $4.75 c$ & $6.14 \mathrm{a}$ & $43.61 \mathrm{c}$ \\
\hline $\mathrm{V}_{1} \times \mathrm{N}_{3}$ & 70.03 & $14.15 b c$ & 11.83 & 20.86 & $115.54 f$ & $12.20 \mathrm{gh}$ & 22.57 & $5.11 b$ & $6.39 a$ & $44.47 b c$ \\
\hline $\mathrm{V}_{1} \times \mathrm{N}_{4}$ & 78.00 & $14.93 a b$ & 13.21 & 20.87 & $114.52 f$ & $10.01 \mathrm{~h}$ & 22.96 & $5.77 a$ & $6.14 \mathrm{a}$ & $48.45 a$ \\
\hline $\mathrm{V} \times{ }_{2} \mathrm{~N}_{0}$ & 75.12 & $8.43 f$ & 6.38 & 23.57 & $122.16 \mathrm{e}$ & $27.77 a$ & 22.82 & $3.55 f$ & $5.12 \mathrm{~cd}$ & $40.94 d$ \\
\hline $\mathrm{V}_{2} \times \mathrm{N}_{1}$ & 73.31 & $10.87 \mathrm{de}$ & 9.52 & 23.08 & $143.72 d$ & $21.68 \mathrm{bcd}$ & 23.21 & $4.57 \mathrm{~cd}$ & $5.38 \mathrm{bcd}$ & $45.95 b$ \\
\hline $\mathrm{V}_{2} \times \mathrm{N}_{2}$ & 73.51 & $13.91 b c$ & 11.96 & 22.89 & $156.20 \mathrm{c}$ & $16.97 \mathrm{ef}$ & 22.38 & $5.07 \mathrm{~b}$ & $5.35 \mathrm{bcd}$ & $48.65 a$ \\
\hline $\mathrm{V}_{2} \times \mathrm{N}_{3}$ & 74.68 & 14.69ab & 13.29 & 23.29 & $182.21 b$ & $10.30 \mathrm{~h}$ & 21.87 & $5.22 b$ & $5.62 b$ & $48.14 a$ \\
\hline $\mathrm{V}_{2} \times \mathrm{N}_{4}$ & 78.02 & $15.68 \mathrm{a}$ & 14.22 & 23.10 & $193.45 a$ & $12.31 \mathrm{gh}$ & 22.36 & $5.82 a$ & $6.09 a$ & $48.86 a$ \\
\hline $\mathrm{V}_{3} \times \mathrm{N}_{0}$ & 73.47 & $5.97 \mathrm{~g}$ & 4.47 & 19.18 & $56.46 \mathrm{k}$ & $23.11 b c$ & 27.92 & $3.58 f$ & $4.63 e$ & $43.57 \mathrm{c}$ \\
\hline $\mathrm{V}_{3} \times \mathrm{N}_{1}$ & 75.60 & $8.64 f$ & 6.05 & 19.49 & 63.93ij & 18.97cde & 27.47 & $4.17 e$ & $5.19 \mathrm{~cd}$ & $44.55 b c$ \\
\hline $\mathrm{V}_{3} \times \mathrm{N}_{2}$ & 73.13 & $9.95 \mathrm{e}$ & 8.17 & 18.81 & $67.95 i$ & 18.63de & 27.26 & 4.38de & $5.16 \mathrm{~cd}$ & $45.90 \mathrm{~b}$ \\
\hline $\mathrm{V}_{3} \times \mathrm{N}_{3}$ & 74.45 & $10.36 \mathrm{e}$ & 8.62 & 19.07 & $69.79 i$ & 16.61efg & 28.43 & $4.68 \mathrm{c}$ & $5.47 \mathrm{bc}$ & $46.07 \mathrm{~b}$ \\
\hline $\mathrm{V}_{3} \times \mathrm{N}_{4}$ & 74.14 & $11.55 d$ & 10.27 & 19.52 & $69.73 \mathrm{i}$ & 15.54efg & 27.67 & $5.15 b$ & $6.13 a$ & $45.67 b c$ \\
\hline CV (\%) & 19.34 & 10.94 & 13.04 & 15.89 & 7.48 & 10.58 & 9.31 & 14.82 & 10.14 & 4.97 \\
\hline $\begin{array}{l}\text { Level of } \\
\text { significance }\end{array}$ & NS & 0.01 & NS & NS & 0.05 & 0.01 & NS & 0.01 & 0.01 & 0.01 \\
\hline
\end{tabular}

In a column, figures with same letters or without letter do not differ significantly whereas figures with dissimilar letter differ significantly (as per DMRT). NS = Not significant; $\mathrm{V}_{1}=\mathrm{BRRI}$ dhan28, V2 = BRRI dhan29, V3 = BRRI dhan45

$\mathrm{N}_{0}=0$ (Control), $\mathrm{N}_{1}=50 \mathrm{~kg} \mathrm{~N} \mathrm{ha}^{-1}, \mathrm{~N}_{2}=100 \mathrm{~kg} \mathrm{~N} \mathrm{ha}^{-1}, \mathrm{~N}_{3}=150 \mathrm{~kg} \mathrm{~N} \mathrm{ha}^{-1}$ and $\mathrm{N}_{4}=200 \mathrm{~kg} \mathrm{~N} \mathrm{ha}^{-1}$

\section{Interaction effect of variety and level of nitrogen}

The interaction of variety and level of nitrogen had significant effect on number of total tiller hill $^{-1}$, number of grains panicle $e^{-1}$, sterile spikelets panicle ${ }^{-1}$, grain yield, straw yield and harvest index. On the other hand, plant height $(\mathrm{cm})$, number of effective tillers hill $^{-1}$, panicle length $(\mathrm{cm})$ and 1000-grain weight $(\mathrm{g})$ were not significantly influenced due to interaction of variety and level of nitrogen (Table 4). The highest number of total tillers hill ${ }^{-1}$ was obtained from the interaction of variety BRRI dhan $29 \times 200$ $\mathrm{kg} \mathrm{N} \mathrm{ha}^{-1}$ which was statistically similar with that of variety BRRI dhan $28 \times 200 \mathrm{~kg} \mathrm{~N} \mathrm{ha}^{-1}$ and BRRI dhan29 $\times 150 \mathrm{~kg} \mathrm{~N} \mathrm{ha}^{-1}$. The highest number of grains panicle ${ }^{-1}$ was obtained from the variety BRRI dhan $29 \times 200 \mathrm{~kg} \mathrm{~N} \mathrm{ha}^{-1}$ and the lowest one was found from the variety BRRI dhan $45 \times$ control $(0 \mathrm{~kg}$ $\mathrm{N} \mathrm{ha}^{-1}$ ) treatment. The highest number of sterile spikelets panicle ${ }^{-1}$ was recorded from the variety BRRI dhan $29 \times$ control $\left(0 \mathrm{~kg} \mathrm{~N}^{-1}\right)$ treatment and the lowest one was observed from the variety BRRI 
dhan $28 \times$ control treatment and variety BRRI dhan 29 $\times$ control $\left(0 \mathrm{~kg} \mathrm{~N} \mathrm{ha}^{-1}\right)$. The highest grain yield (5.82 $\mathrm{t} \mathrm{ha}^{-1}$ ) was obtained in BRRI dhan29 with $200 \mathrm{~kg} \mathrm{~N}$ $\mathrm{ha}^{-1}$ which was statistically similar to combination of BRRI dhan28 with $200 \mathrm{~kg} \mathrm{~N}^{-1}\left(5.77 \mathrm{t} \mathrm{ha}^{-1}\right)$. The lowest grain yield $\left(3.49 \mathrm{t} \mathrm{ha}^{-1}\right)$ was obtained from BRRI dhan28 with $0 \mathrm{~kg} \mathrm{~N} \mathrm{ha}^{-1}$. The highest straw yield was recorded from the interaction of BRRI dhan28 with $150 \mathrm{~kg} \mathrm{~N} \mathrm{ha}^{-1}$ which was statistically identical with that of BRRI dhan28 with $200 \mathrm{~kg} \mathrm{~N}$

\section{References}

Babiker FSH (1986). The effect of zinc sulphate levels on rice growth and productivity. Alexandria J. Agric. Res. 31 (2): 480-481.

BADC, Bangladesh Agricultural Development Corporation (2008). Minor irrigation survey report 2007-08. Ministry of Agriculture, Dhaka, Bangladesh

Balasubramaniyan P (1984). Nitrogen fertilization for short duration rice. Int. Rice Res. Newsl. 9(5): 29.

Bali AS, Siddique M, Ganai BA, Khan HV, Singh KN, Bali AS (1995). Response of rice (Oryza sativa) genotypes to nitrogen levels under transplanted conditions in Kashmir valley. Indian J. Agron. 40(1): 35-37.

BRRI, Bangladesh Rice Research Institute (1985). Annual report for 1981. BRRI Pub. No. 71. Joydebpur, Gazipur, Bangladesh. pp.2-8.

BRRI, Bangladesh Rice Research Institute (1994). Annual Report July 1994-June 1995. Bangladesh Rice Res. Inst. Joydebpur, Gazipur, Bangladesh. pp. 36-37.

Chowdhury MJU, Sarker AU, Sarker MAR, Kashem MA (1993). Effect of variety and number of seedlings hill-1 on the yield and its components on late transplanted aman rice. Bangladesh J. Agril. Sci. 20 (2): 311-316.

Diaz SH, Castro R, Morejon R (2000). Morphoagronomic characterization of varieties of rice. Instituto Nacional de ciencias Agricolas, Gaveta Postall, San Jose, de las, Lajsa, La Habna. 21(3): 81-86. ha $^{-1}$ and BRRI dhan28 with $200 \mathrm{~kg} \mathrm{~N} \mathrm{ha}^{-1}$ and BRRI dhan29 × $200 \mathrm{~kg} \mathrm{~N} \mathrm{ha-1}$. The highest harvest indexwas observed in variety BRRI dhan29 with 200 $\mathrm{kg} \mathrm{N} \mathrm{ha}^{-1}$ which was statistically similar with the interactions of BRRI dhan29 $\times 100 \mathrm{~kg} \mathrm{~N} \mathrm{ha}^{-1}$, BRRI dhan28 $\times 200 \mathrm{~kg} \mathrm{~N}^{-1}$ and BRRI dhan $29 \times 150 \mathrm{~kg}$ $\mathrm{N}$ ha $^{-1}$. From the results of the study it may be concluded that BRRI dhan29 rice may be cultivated with $200 \mathrm{~kg} \mathrm{~N} \mathrm{ha}^{-1}$ for obtaining higher yield in AEZ 9 of Bangladesh.

Daniel KV, Wahab K (1994). Levels and time of nitrogen in semi dry rice. Madras Agric. J. 81(6): 357-358.

Ghosh BC, CV Raghavaian, MK Jana (1991). Effect of seedrate and nitrogen on growth and yield of direct sown rice (Oryza sativa L.) under intermediate deep water condition. Indian J. Agron. 36: 227-228.

GOB, Government of Bangladesh (1998). Minor irrigation survey report, 1997-98. Bangladesh Agriculture Development Corporation, Ministry of Agriculture, Dhaka, Bangladesh.

Gomez KA, Gomez AA (1984). Statistical Procedure for Agricultural Research. $2^{\text {nd }}$ Ed. John Wiley and Sons. New York, pp.643-645.

Hussain T, Jilani G Ghaffar A (1989). Influence of rate and time of nitrogen application on growth and yield of rice in Pakistan. Inter. Rice. Res. Newsl. 14(6): 18.

Kumar M, Haque M, Singh SB, Pathak SK (1996). Effect of graded levels of nitrogen on yield and quality of scented rice varieties in southern alluvial Gangetic plants of Bihar. J. Appl. Biol. 6: 61-63.

Marazi AR, Khan GM, Singh KH, Bali AS (1993). Response of rice (Oryza sativa) to different $\mathrm{N}$ levels and water regimes in Kashmir Valley. Indian J. Agric. Sci. 63(11): 726727.

Meena SL, Surendra S, Shivay YS, Singh S (2003). Response of hybrid rice (Oryza sativa) to nitrogen and potassium application in sandy clay loam soils. Indian J. Agric. Sci. 73(1): 8-11. 
Pandey SK, Rajkumar RS, Singh BB (1991). Effect of different doses of nitrogen on dwarf and tall varieties of rice (Oryza sativa). Indian J. Agril. Sci. 61(2): 135-138.

Shamsuddin AM, Islam MA, Hossain A (1988). Comparative study on the yield and agronomic characters of nine cultivars of aus rice. Bangladesh. J. Agril. Sci. 15(1): 121-124.
Thakur RB (1993). Performance of summer rice (Oryza sativa) to varying levels of nitrogen. Indian J. Agron. 38(2): 187-190.

UNDP, FAO (1988). Land Resources Appraisal of Bangladesh for Agricultural Development. Report 2. Agro-ecological Regions of Bangladesh. United Nation Develop. Prog. Food and Agric. Org. pp. 212-221. 